\title{
Characterization of Sullage Collected from Residential Building
}

\author{
B. Saritha, Chockalingam M.P, L Maria Subashini
}

\begin{abstract}
The present study is about the analysis of sullage collected from Tiruvanchery region, Chennai, Tamil Nadu, India. Sullage is the waste water from households, sinks, bathrooms, kitchen households but except the waste water from toilets. In this project, 6 samples of waste water were collected in 3 different apartments. The apartments are Ruby Grand, Ruby Regency and Green Paradise. The 2 samples of the waste water are the kitchen waste water and washing clothes waste water. Physical, chemical and biological parameters are tested in environmental laboratory. The chemical parameters were tested using titrimetric method. It is found that all samples were safe against pH, Alkalinity, Flouride, Chloride, Iron, Phosphate, and Turbidity which are within the permissible limits of IS3306 (1974).
\end{abstract}

Keywords - Sullage-water, physio-chemical analysis, BOD-COD analysis, treatment methods.

\section{INTRODUCTION}

Sullage is the impure water which contains bacteria and soil contents. Water is one of the most important substances on earth[1]-[5]. Water pollution is an addition of foreign substances either organic/inorganic or biological or radio-active substances into water in excess, which alters the quality of water and which may be pose health hazard.

Water pollution effects the entire biosphere plants and organisms living in these bodies of water. The study of sullage was carried out to determine the physio-chemical and biological parameters of the sullage collected from residential building and to appreciate the opportunity of building a wastewater treatment plant.

Sullage is the waste water from household sinks, showers, and baths, but not waste liquid or excreta from toilets. The application of grey-water reuse in urban water systems provides substantial benefits for both the water supply subsystem by reducing the demand for fresh clean water as well as the wastewater subsystems by reducing the amount of wastewater required to be conveyed and treated[6]-[9].

Sullage doesnot contain high level microorganisms that make it unsuitable for spray irrigation. Sullage can also be used for irrigation purposes. Sullage is generally safer to handle and easier to treat and reuse onsite for toilet flushing,

Revised Manuscript Received on October 22, 2019.

B. Saritha, Department of Civil Engineering, Bharath Institute of Higher Education and Research, Chennai , India. Email: sarichaks@ gmail.com

Chockalingam M.P, Department of Civil Engineering, Bharath Institute of Higher Education and Research, Chennai , India. Email: chocklingamfp@gamil.com

L Maria Subashini, Department of Civil Engineering, Bharath Institute of Higher Education and Research, Chennai, India. Email: mariasubashini80@gmail.com landscape or crop irrigation and other non-potable uses. Salts and phosphorus from laundry detergents are pollutants.

\section{OBJECTIVES}

The main objective of the study is to :

Find the physical, chemical and biological characteristics of sullage collected from Tiruvanchery region.

Compare the analysed sample against IS 3025 (Part -I) 1987.

$>$ Suggest reuse and recycle of sullage[10]-[13].

Table 1: Sullage Sample Collected From Tiruvanchery Region, Chennai

\begin{tabular}{|c|c|c|c|c|c|c|c|}
\hline \multirow{2}{*}{$\begin{array}{l}\text { Sl. } \\
\text { No. }\end{array}$} & \multirow[t]{2}{*}{ Parameters } & \multicolumn{2}{|c|}{ Ruby Grand } & \multicolumn{2}{|c|}{ Ruby Regency } & \multicolumn{2}{|c|}{ Green Paradise } \\
\hline & & A & B & A & B & A & B \\
\hline 1. & $\mathrm{pH}$ & 7.0 & 8.5 & 7.0 & 8.0 & 7.5 & 7.0 \\
\hline 2. & $\begin{array}{l}\text { Alkalinity } \\
(\mathrm{mg})\end{array}$ & 40 & 80 & 16 & 20 & 50 & 45 \\
\hline 3. & Hardness & 75 & 90 & 40 & 45 & 75 & 70 \\
\hline 4. & Chloride (mgl) & 24 & 50 & 25 & 30 & 35 & 30 \\
\hline 5. & $\begin{array}{l}\text { Total Diss olvedSolids } \\
\text { (mgl) }\end{array}$ & 166.8 & 264 & 97.2 & 114 & 192 & 174 \\
\hline 6. & Fuperide $(\mathrm{m} g \mathrm{ll})$ & 1.0 & 0.5 & 0.5 & 1.0 & 1.0 & 0.5 \\
\hline 7. & $\operatorname{Ig} \mathrm{n}(\mathrm{mg} \mathrm{g})$ & 0.3 & 0.3 & 0.3 & 0.3 & 0.3 & 0.3 \\
\hline 8. & Ammonia (mgl) & 0 & 1.0 & 0 & 0.5 & 0 & 0.5 \\
\hline 9. & Nitrite (mgl) & 0.2 & 0.5 & 0.2 & 0.2 & 0.2 & 0.5 \\
\hline 10. & Nitrite (mg/) & 20 & 45 & 45 & 20 & 20 & 45 \\
\hline 11. & Residua lchloging (m gl) & 0.2 & 0.5 & 0.2 & 0.5 & 0.2 & 0.5 \\
\hline 12 . & Phosphate (mgl) & 3.0 & 0.5 & 2.7 & 2.3 & 2.5 & 2.1 \\
\hline 13. & Conductivity (mgl) & 1.79 & 3.12 & 1 & 2.0 & 2.0 & 1.0 \\
\hline 14. & $\mathrm{BOD}(\mathrm{mg} /)$ & 245 & 260 & 250 & 265 & 243 & 260 \\
\hline 15. & $\mathrm{COD}(\mathrm{mg})$ & 540 & 620 & 550 & 625 & 535 & 620 \\
\hline
\end{tabular}

$\mathrm{A}=$ Kitchen wastewater $\mathrm{B}=$ Clothes wastewater

Table 4.2: Quality Standards Of Treated Waste Water

\begin{tabular}{|c|c|c|c|c|c|c|c|c|}
\hline Standards & & $\mathrm{pH}$ & $\begin{array}{l}\text { BOD } \\
\mathrm{mg} / \mathrm{L}\end{array}$ & $\begin{array}{l}\text { Turbi dity } \\
\text { (NTU) }\end{array}$ & $\begin{array}{l}\text { TSS } \\
\mathrm{mg} / \mathrm{L}\end{array}$ & $\begin{array}{c}\mathrm{FC} \\
\mathrm{cfu} / 100 \\
\mathrm{ml}\end{array}$ & $\mathrm{RC} \operatorname{mg} \mathrm{L}$ & Refarence \\
\hline \multirow[t]{3}{*}{$\begin{array}{l}\text { CPCB } \\
\text { India }\end{array}$} & $\begin{array}{l}\text { On land for } \\
\text { isriegtion". }\end{array}$ & $5.5-9$ & 100 & - & 200 & - & - & \multirow[t]{3}{*}{$\begin{array}{l}\text { CPCB (2008) } \\
\text { (ref: } 44)\end{array}$} \\
\hline & $\begin{array}{l}\text { Into inland } \\
\text { surface water" }\end{array}$ & $5.5-9$ & 30 & - & 100 & - & 1 & \\
\hline & $\begin{array}{l}\text { Into Public } \\
\text { selowerse }\end{array}$ & $5.5-9$ & 350 & - & 600 & - & - & \\
\hline \multirow[t]{2}{*}{ USEPA } & $\begin{array}{l}\text { Unrestricted } \\
\text { use }^{d}\end{array}$ & $6-9$ & 10 & 2 & - & 0 & 1 & \multirow[t]{2}{*}{$\begin{array}{c}\text { USEPA } \\
\text { (2012) (ref: } \\
46)\end{array}$} \\
\hline & Restricted yse $e^{*}$ & $6-9$ & 30 & - & 30 & 200 & 1 & \\
\hline
\end{tabular}




\section{RESULTS AND DISCUSSIONS}

In the graph ,the $\mathrm{pH}$ of all sullage samples are shown.

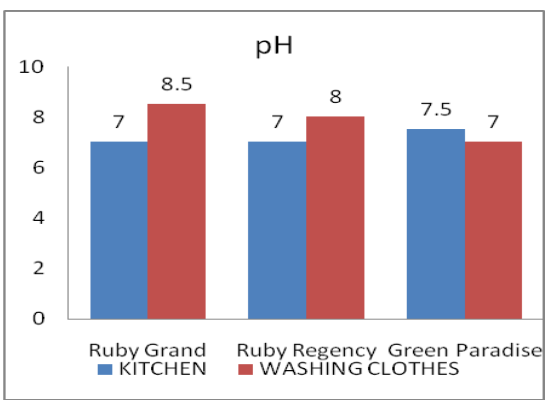

Figure - 1 pH

In the graph, the alkalinity of all sullage samples are shown

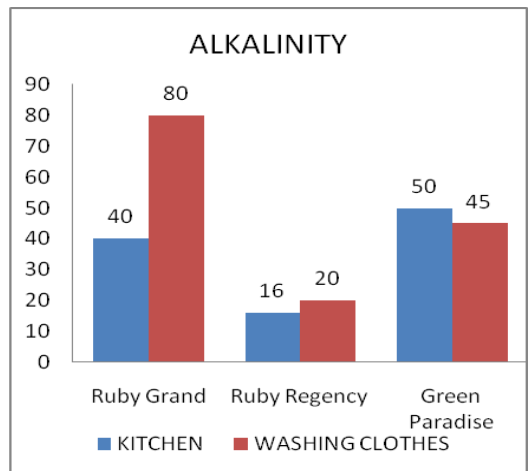

Figure - 2 Alkanity

. In the graph ,the hardness of all sullage samples are shown. Little amount of the sullage samples were not safe.

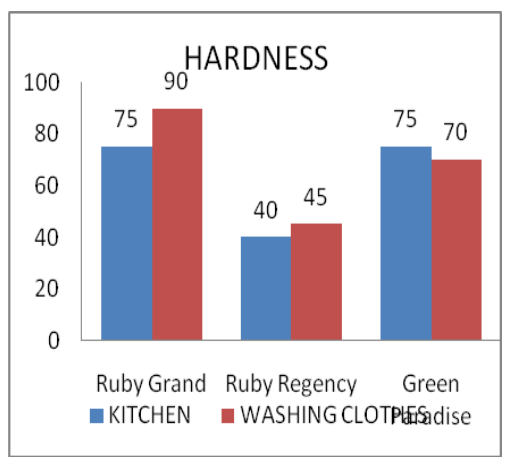

Figure - 3 Hardness

In the graph, the chloride of all sullage samples are shown. Little amount of the sullage samples were not safe. This may be due to fertilizers, residential wastes and minerals[14]-[18].

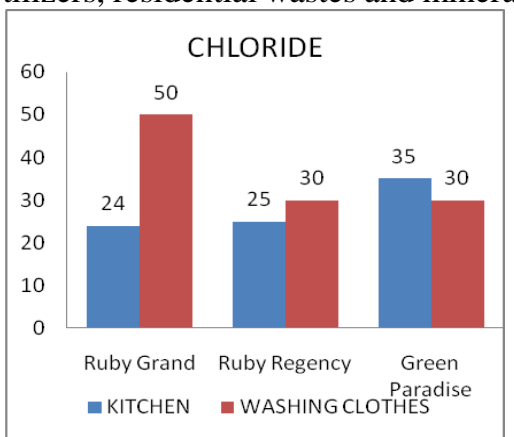

Figure - 4 Chloride
In the graph ,the TDS of all sullage samples are shown. Little amount of the sullage samples were not safe. This may be due to livestock waste, septic system, dissolved minerals, iron and manganese.

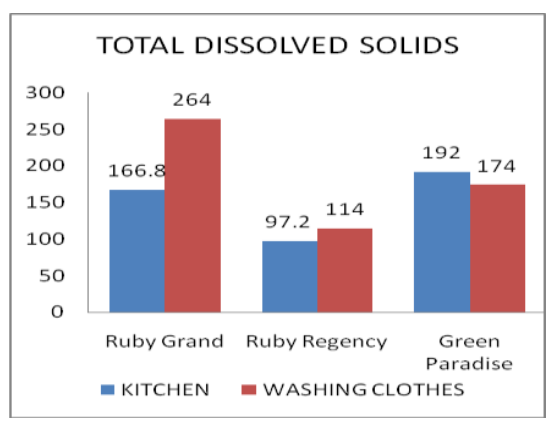

Figure - 5 Total Dissolved Solids

In the graph, the flouride of all sullage samples are shown.

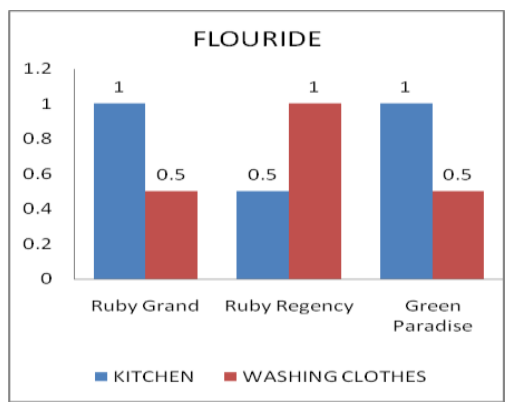

Figure - 6 Flouride

In the graph ,the Iron level of all sullage samples are shown. Little amount of the sullage samples were not safe. This may be due to leaching of cast iron pipes sin water distribution system[19]-[22].

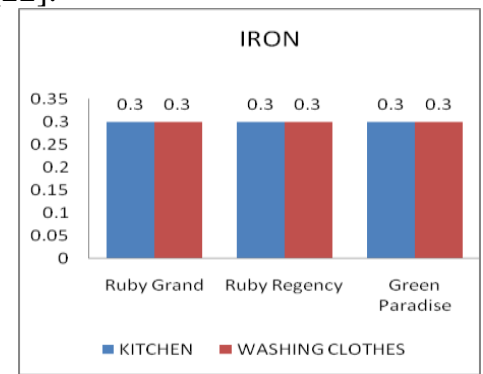

Figure - 7 Ammonia

In the graph ,the Ammonia of all sullage samples are shown. This may be due to improper waste disposal.

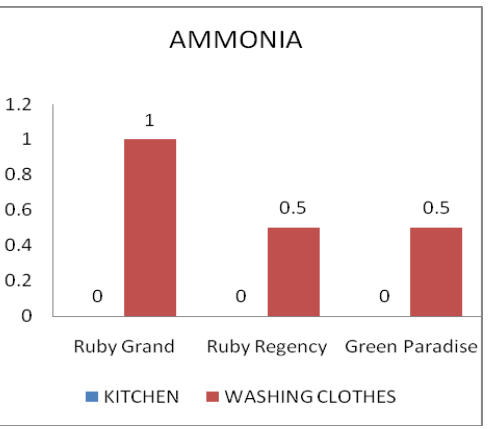

Figure - 8 Iron 
In the graph ,the Nitrite of all sullage samples are shown.

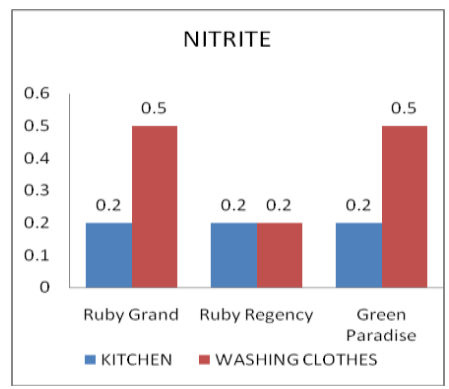

Figure - 9 Nitrite

In the graph ,the Nitrate of all sullage samples are shown. Little amount of the sullage samples were not safe. This may be due to livestock facilities, septic systems, manure lagoons, household waste water, fertilizers and natural deposits[23]-[29].

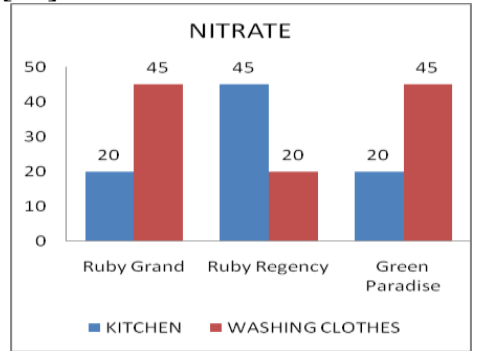

Figure - 10 Nitrate

In the graph ,the Residual Chlorine of all sullage samples are shown.

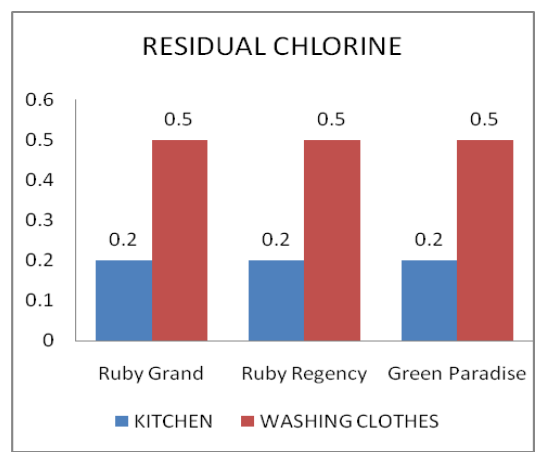

Figure - 11 Residual chlorine

In the graph ,the Phosphateof all sullage samples are shown.

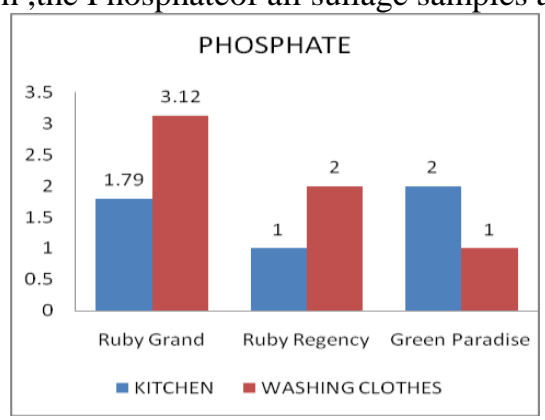

Figure - 12 Phosphate

In the graph ,the Conductivity of all sullage samples are shown.

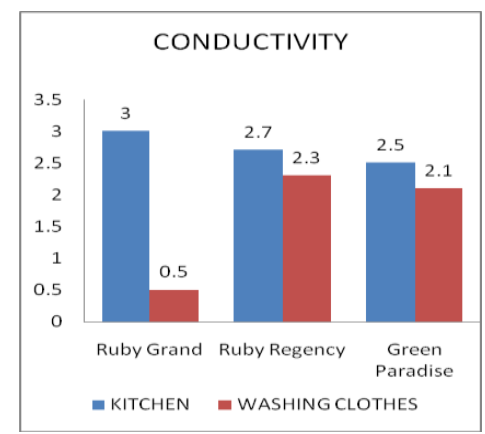

Figure - 13 Conductivity

In the graph ,the BOD of all sullage samples are shown.

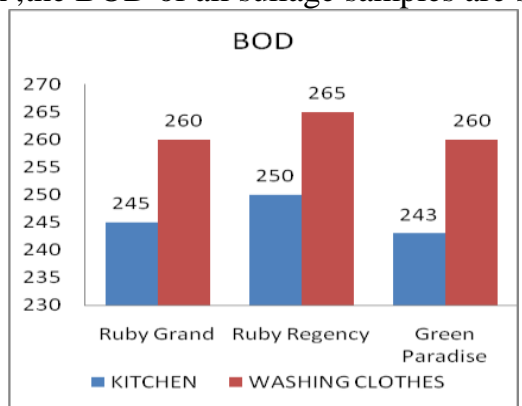

Figure - 14 BOD

In the graph ,the COD of all sullage samples are shown.

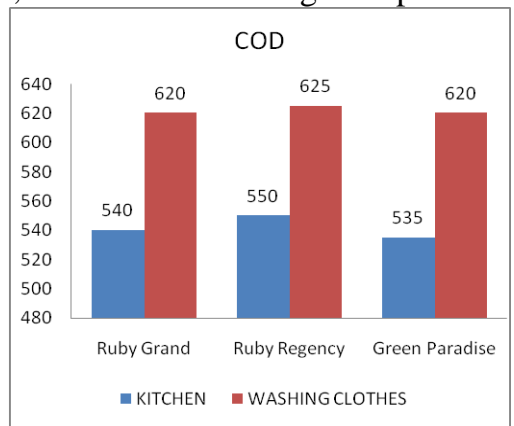

Figure - 14 COD

\section{CONCLUSION}

The project has been carried out by collecting the sample (sullage) from the selected areas of Tiruvanchery region (Ruby Grand, Ruby Regency and Green Paradise). Two samples each has been collected from each area which includes kitchen wastewater and clothes wastewater[30]-[36]. The results showed that all the samples were safe against $\mathrm{pH}$, Alkalinity, Flouride, Chlorine, Iron and Phosphate which were found to be within the permissible limits of IS3360 (1974). Thus, there may not be any treatment required for the above parameters. However, the water should be treated against Hardness, Total Dissolved Solids (TDS), Ammonia, Nitrate, Nitrite and conductivity as they are not found within the permissible limits of IS3360 (1974). From the results the waste water can be used for irrigation purposes.

The project was successfully completed by suggesting the possible treatment method for the sullage water. 


\section{REFERENCES}

1. Iyappan L., Dayakar P., Identification of landslide prone zone for coonoortalukusing spatial technology, International Journal of Applied Engineering Research,V-9,I-22,PP-5724-5732,Y-2014.

2. Kumar J., Sathish Kumar K., Dayakar P.,Effect of microsilica on high strength concrete, International Journal of Applied Engineering Research,V-9,I-22,PP-5427-5432,Y-2014.

3. Dayakar P., Vijay Ruthrapathi G., Prakesh J., Management of bio-medical waste, International Journal of Applied Engineering Research,V-9,I-22,PP-5518-5526,Y-2014.

4. Swaminathan N., Dayakar P., Resource optimization in construction project, International Journal of Applied Engineering Research,V-9,I-22,PP-5546-5551,Y-2014.

5. Venkat Raman K., Dayakar P., Raju K.V.B.,An experimental study on effect of cone diameters in penetration test on sandy soil, International Journal of Civil Engineering and Technology,V-8,I-8,PP-1581-1588,Y-2017.

6. Saritha B., Chockalingam M.P.,Photodradation of malachite green DYE using TIO2/activated carbon composite,International Journal of Civil Engineering and Technology,V-8,I-8,PP-156-163,Y-2017

7. Shendge R.B., Chockalingam M.P., Saritha B., Ambica A.,Swat modelling for sediment yield: A case study of Ujjani reservoir in Maharashtra, India,International Journal of Civil Engineering and Technology,V-9,I-1,PP-245-252,Y-2018

8. Chockalingam M.P., Balamurgan V.,Modernisation of an existing urban road-sector in Chennai, a case study report,International Journal of Civil Engineering and Technology,V-8,I-8,PP-1457-1467,Y-2017

9. Saritha B., Chockalingam M.P.,Adsorption study on removal of basic dye by modified coconut shell adsorbent, International Journal of Civil Engineering and Technology,V-8,I-8,PP-1370-1374,Y-2017

10. Saritha B., Chockalingam M.P.,Adsorptive removal of heavy metal chromium from aqueous medium using modified natural adsorbent,International Journal of Civil Engineering and Technology,V-8,I-8,PP-1382-1387,Y-2017

11. Chockalingam M.P., Palanivelraja S.,Retrospective analysis of a theoretical model used for forecasting future air quality near the north Chennai thermal power plant,International Journal of Civil Engineering and Technology,V-8,I-8,PP-1457-1467,Y-2017

12. Saritha B., Chockalingam M.P.,Photodegradation of methylene blue dye in aqueous medium by $\mathrm{Fe}-\mathrm{AC} / \mathrm{TiO} 2$ Composite,Nature Environment and

Pollution Technology,V-17,I-4,PP-1259-1265,Y-2018

13. Shendge R.B., Chockalingam M.P., Kaviya B., Ambica A.,Estimates of potential evapotranspiration rates by three methods in upper Bhima Basin, In Maharashtra, India,International Journal of Civil Engineering and Technology,V-9,I-2,PP-475-480,Y-2018

14. Shendge R.B., Chockalingam M.P.,The soil and water assessment tool for Ujjani Reservoir,International Journal of Mechanical Engineering and Technology,V-9,I-2,PP-354-359,Y-2018

15. Shendge R.B., Chockalingam M.P.,A review on soil and water assessment tool,International Journal of Mechanical Engineering and Technology,V-9,I-2,PP-347-353,Y-2018

16. Sachithanandam P., Meikandaan T.P., Srividya T.,Steel framed multi storey residential building analysis and design,International Journal of Applied Engineering Research,V-9,I-22,PP-5527-5529,Y-2014

17. Meikandaan T.P., Ramachandra Murthy A.,Study of damaged RC beams repaired by bonding of CFRP laminates,International Journal of Civil Engineering and Technology,V-8,I-2,PP-470-486,Y-2017

18. Meikandaan T.P., Ramachandra Murthy A.,Retrofittng of reinforced concrete beams using GFRP overlays,International Journal of Civil Engineering and Technology,V-8,I-2,PP-423-439,Y-2017

19. Meikandaan T.P., Ramachandra Murthy A.,Flexural behaviour of RC beam wrapped with GFRP sheets,International Journal of Civil Engineering and Technology,V-8,I-2,PP-452-469,Y-2017

20. Meikandaan T.P., Murthy A.R.,Experimental study on strengthening of rc beams using glass Fiber,International Journal of Civil Engineering and Technology,V-9,I-11,PP-959-965,Y-2018

21. Meikandaan T.P., Hemapriya M.,Use of glass FRP sheets as external flexural reinforcement in RCC Beam,International Journal of Civil Engineering and Technology,V-8,I-8,PP-1485-1501,Y-2017

22. Saraswathy R., Saritha B.,Planning of integrated satellite township at Thirumazhisai,International Journal of Applied Engineering Research,V-9,I-22,PP-5558-5560,Y-2014

23. Saritha B., Ilayaraja K., Eqyaabal Z.,Geo textiles and geo synthetics for soil reinforcement,International Journal of Applied Engineering Research,V-9,I-22,PP-5533-5536,Y-2014
24. Ambica A., Saritha B., Changring G., Singh N B., Rajen M., Salman Md.,Analysis of groundwater quality in and around Tambaram taluk, Kancheepuram district,International Journal of Civil Engineering and Technology,V-8,I-8,PP-1362-1369,Y-2017

25. Arunya A., Sarayu K., Ramachandra Murthy A., Iyer N.R.,Enhancement of durability properties of bioconcrete incorporated with nano silica,International Journal of Civil Engineering and Technology,V-8,I-8,PP-1388-1394,Y-2017

26. Ilayaraja K., Krishnamurthy R.R., Jayaprakash M., Velmurugan P.M., Muthuraj S.,Characterization of the 26 December 2004 tsunami deposits in Andaman Islands (Bay of Bengal, India),Environmental Earth Sciences, V-66,I-8,PP-2459-2476,Y-2012

27. Ilayaraja K.,Morphometric parameters of micro watershed in Paravanar sub-basin, Cuddalore District,International Journal of Civil Engineering and Technology,V-8,I-8,PP-1444-1449,Y-2017

28. Ilayaraja K., Singh R.K., Rana N., Chauhan R., Sutradhar N.,Site suitability assessment for residential areas in south Chennai region using remote sensing and GIS techniques,International Journal of Civil Engineering and Technology,V-8,I-8,PP-1468-1475,Y-2017

29. Ilayaraja K., Reza W., Kumar V., Paul S., Chowdhary R.,Estimation of land surface temperature of Chennai metropolitan area using Landsat images,International Journal of Civil Engineering and Technology, V-8,I-8,PP-1450-1456,Y-2017

30. Chitra R.,Experimental study on beam using steel fiber and latex,International Journal of Civil Engineering and Technology,V-8,I-8,PP-1395-1403,Y-2017

31. Chitra R.,Analysis of traffic and management at Kovilambakkam intersection,International Journal of Civil Engineering and Technology,V-8,I-8,PP-1433-1443,Y-2017

32. Aswathy M.,Experimental study on light weight foamed concrete,International Journal of Civil Engineering and Technology,V-8,I-8,PP-1404-1412,Y-2017

33. Aswathy M.,Wastewater treatment using constructed wetland with water lettuce (Eichornia Crasipies),International Journal of Civil Engineering and Technology,V-8,I-8,PP-1413-1421,Y-2017

34. Kiruthiga K., Anandh K.S., Gunasekaran K, Assessment of influencing factors on improving effectiveness and productivity of construction engineers, 2015, International Journal of Applied Engineering Research, V - 10,I -17,p -13849-13854

35. Srinivasan, G.R. \& Palani, S. 2018, "Physicochemical analysis and economic evaluation of lake ecosystem - A case study of lake system in Walajah Taluk, Vellore (India)", Water and Energy International, vol. 61RNI, no. 3, pp. 52-55.

36. Srinivasan GR, Palani S, Manohanam A, Jambulingam R. Assessment of Groundwater Quality of Water Samples Collected From Vellore Co-Operative Sugar Mill, Vellore. Asian Man (The)-An International Journal. 2018;12(2):216-8.

\section{AUTHORS PROFILE}

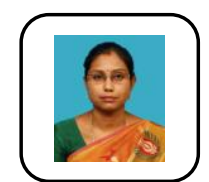

B. Saritha Assistant Professor, Department of Civil Engineering, Bharath Institute of Higher Education and Research, Chennai, India.

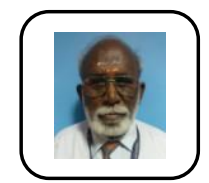

Chockalingam M.P Adjunct faculty, Department of Civil Engineering, Bharath Institute of Higher Education and Research, Chennai , India.

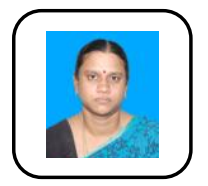

L Maria Subashini Assistant Professor, Department of Civil Engineering, Bharath Institute of Higher Education and Research, Chennai, India. 